\title{
The Effect of Calcium on Photosynthetic Rate due to ABA and Proline Behaviour of Oil Palm (Elaeis guineensis Jacq.) Seedlings under Drought Conditions
}

\author{
Endah Nurwahyuni* and Eka Tarwaca Susila Putra \\ Department of Agronomy, Faculty of Agriculture, Gadjah Mada University, Yogyakarta, Indonesia \\ *Corresponding author: nurwahyuni.endah@gmail.com
}

\begin{abstract}
Planting drought-resistance plants in terms of agronomy, such as induction of plant tolerance using calcium is assumed to be able to solve the climate anomaly problem. Calcium is known as an element that plays an essential role in determining the response of plant resistance to drought through biochemical activity. This study aimed to determine the role of calcium in changing photosynthesis activity in order to increase the resistance to drought stress. The treatment was arranged in factorial of $3 \times 4$ in a split plot Randomized Complete Block Design replicated three times. The first factor was the dose of calcium application consisted of 0 (control/without calcium), $0.04,0.08$ and $0.12 \mathrm{~g}$. The second factor was the intensity of drought stress, which referred to the Fraction of Transpirable Soil Water method consisted of 1 (control/field capacity), 0.35 (moderate drought) and 0.15 (severe drought). The measurement data of stomatal aperture, Abscisic Acid (ABA) content, chlorophyll content, carotenoid content, proline content, nitrate reductase activity and photosynthesis rate that fulfill the assumption of homogeneity and normality were analyzed using variance at 95\% accuracy and continued using DMRT. Moreover, regression analysis were determined of relationship between the treatment and parameters. The results revealed that drought resulted in a decline in leaf water potential and stomatal aperture. The effects of calcium on chlorophyll and carotenoid under drought stress could not be explained in this study. However, the application of calcium has a significant effect on decreased ABA, increased proline and nitrate reductase activity resulting in an increase in the photosynthetic rate of oil palm seeds in drought stress.
\end{abstract}

Keywords: ABA, carotenoid, chlorophyll, NRA, proline

Cite this as: Nurwahyuni, E., \& Putra, E. T. S. (2019). The Effect of Calcium on Photosynthetic Rate due to ABA and Proline Behaviour of Oil Palm (Elaeis guineensis Jacq.) Seedlings under Drought Conditions. Caraka Tani: Journal of Sustainable Agriculture, 34(1), 31-42. doi: http://dx.doi.org/10.20961/carakatani.v34i1.28264

\section{INTRODUCTION}

Drought is the result of global climate change that harms plant growth and development, including oil palm. It was reported that the effects of drought in Sumatera, Indonesia had resulted in a 60\% decrease in palm oil productivity (Darlan et al., 2016). There was 10\% reduction throughout the year in production at every $100 \mathrm{~mm}$ of rainwater deficit (Carr, 2011). Plants response to drought stress through some biochemical, physiological and growth changes (Suguiyama et al., 2016). Some of biochemical responses are closely related to photosynthetic activity including the decrease in leaf water potential, osmotic adjustment, osmotic protectant accumulation such as sugar alcohols, amino acids and organic acids (Bivi et al., 2016), the decreasing in carbon assimilation for photosynthesis due to stomatal closure, decreasing chloroplasts (Parry et al., 2005; Shekari et al., 2015) and photosystem II activity (Shekari et al., 2015). The tolerant cultivar that

\footnotetext{
* Received for publication February 28, 2019

Accepted after corrections March 14, 2019
} 
have better resistance to drought still showed a marked decrease in production by more than 50 percent due to the decline in photosynthesis efficiency (Jazayeri et al., 2015). However, drought considerably hampered the process of photosynthesis in most plants by altering the ultrastructure of the organelles and concentration of various pigments and metabolites including enzymes involved in this process as well as stomatal regulations (Ashraf and Harris, 2013).

Cultivation treatments were applied to overcome the problems by inducing calcium to strengthen plant resistance to the drought. Moreover, calcium has been well known to have an essential role in overcome abiotic stress, one of which is drought. It is an essential secondary messenger in the signal transduction pathway for various resistance responses. It was reported that $\mathrm{Ca}^{2+}$ ions were involved in a variety of basic regulation and process such as cytoplasmic flow, thigmotropism, gravitropism (Song et al., 2008), cell division, cell elongation, cell development, cell polarity, photomorphogenesis, plant defense and stress response (Reddy, 2001). It is involved in Abscisic Acid (ABA) transduction in guard cells, regulates the rate of transpiration, inhibits synthesis of reactive oxygen species (ROS), reduces malondialdehyde (MDA), increases antioxidant enzyme activity, increases enzyme catalase and proline content, protects plasma membrane structure, increases Rubisco activity, maintains photosynthetic efficiency, maintains nitrogen assimilation, regulates hormone metabolism and other essential chemicals as well. In addition to secondary messenger in conveying drought signals by regulating various physiological responses ( $\mathrm{Li}$ et al., 2003; Shao et al., 2008; Song et al., 2008; Naeem et al., 2017).

Previous studies examined the induction of plant resistance using Silica and Boron. The application of Silica to oil palm seedlings can induce physiological resistance of oil palm seeds through increasing leaf greenery and decreasing the density of abaxial stomata (Dewi et al., 2014; Putra et al., 2015; Wirawan et al., 2016) while boron can increase green leaf index, stomatal aperture and photosynthetic activity per plant (Solihatun et al., 2014; Putra et al., 2016). However, the responses of plants to silica addition were more complex and it would risk producing severe toxicity if it had been applied on a large scale. On the other hand, the level of boron's sufficiency for plants have a narrow range so that it will be deficient in fewer quantities, but if it has the excessive quantities, it will be poison. Calcium is more likely to be carried out and has the potential to be successfully which applied on a broader scale in seedlings and higher plants since the plant's need for calcium that relatively high, so it is less possible to experience an overdose. Furthermore, the addition of calcium is useful for increasing the number of cations and improving soil fertility. It was improved the land optimization and supporting sustainable agriculture. This research aims to find out the role of calcium in the process of changing the photosynthesis activity of oil palm, especially in order to increase the resistance to drought stress.

\section{MATERIALS AND METHOD}

The experiment was conducted in August 2017 - May 2018 in oil palm nursery, Bendosari, Madurejo Village, Prambanan Sub-district, Sleman District, Special Region of Yogyakarta. The observation of biochemical parameters was conducted in May - July 2018 at Plant Production Management Laboratory Faculty of Agriculture, Gadjah Mada University, Yogyakarta. The materials consist of Avros cultivar seeds that become a cultivar that was considered intolerant to drought from the Palm Oil Research Center, Medan. Planting media used was alfisols soil which had low fertility, calcium fertilizer $\left(\mathrm{CaSO}_{4}\right)$ pure analysis (PA) and NPK fertilizer for maintaining the seedlings.

Experiments were arranged according to the two-factorial randomized complete block design (RCBD). The first factor was drought stress consisted of FTSW (Fraction of Transpirable Soil Water) 1 (control/field capacity), FTSW 0.35 (moderate drought) and FTSW 0.15 (severe drought). The second factor was the application of calcium $\left(\mathrm{CaSO}_{4}\right)$ consisted of 0 (no calcium/control), 0.04 gram; 0.08 gram and 0.12 gram. Each treatment combination consisted of nine plants that had been repeated three times with blocks as replications.

Seedlings maintained for four months at prenursery included irrigation, weed control and fertilization. The fertilizer given was NPK $(15: 15: 15)$ with a dose of 3 gram per polybag applied every two weeks. Four months after transplanting (m.a.t) the seeds were transplanted and maintained during acclimatization in the main nursery for two months. The fertilizer given at the 
main nursery stage was NPK $(15: 15: 15)$ with a dose of 5 gram per polybag. The calcium was given once in a ring placement starting when the seeds were 5 m.a.t. The calcium used was $\mathrm{CaSO}_{4}$ (PA). Drought experiments were carried out by measuring the content of soil water that could be transpired (FTSW $=$ fraction of transpirable soil water) referred to the method proposed by Ray and Sinclair (1998). The polybag was filled with water, then weighed as field capacity (FC) when the water was not dripping. The polybag was left until the weight did not back decrease (stable) then weighed as a permanent wilting point (PWP). The weight of each level target of FTSW was determined by the equation according to Ray and Sinclair (1998).
The stress level of each plant was expressed as a function of soil water content. The rate of groundwater transpiration in each polybag on a

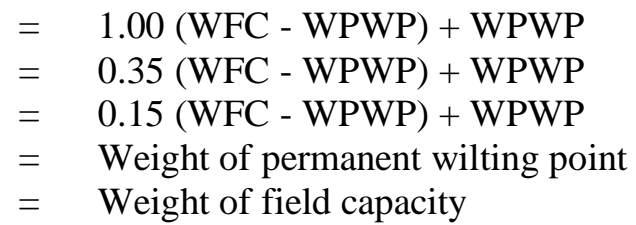

particular day was calculated by the following equation:

$$
F T S W=\frac{\text { weight of polybag on day } 1-\text { weight of final polybag }}{\text { The weight of the initial polybag }- \text { the weight of the final polybag }}
$$

Drought treatment was started at the age of eight months. The experiment was carried out for three weeks, two months after the application of calcium. That was the time when the seeds had been growing for six months then acclimatized. Environmental characteristics such as air temperature, relative air humidity and light intensity were measured every day at $09.00 \mathrm{am}$, $12.00 \mathrm{pm}$ and $3.00 \mathrm{pm}$.

The variables included leaf water potential, stomatal aperture, proline content, nitrate reductase activity, chlorophyll a content, chlorophyll $b$ content, total chlorophyll content, carotenoids content and photosynthesis rates. For all these measurements, the material was a leaf organ, especially one that was located on the top of the canopy and had perfectly expanded. The leaf water potential $\left(\Psi_{\mathrm{w}}\right)$ was measured using a pressure chamber instrument model 1000, while stomatal aperture measurements using the method developed by Hilu and Randall (1984). Analysis of nitrate reductase activity was performed using a method developed by Hartiko (1987), while proline content in leaf tissue was extracted and analyzed according to the method proposed by Bates et al. (1973). Chlorophyll and carotenoid contents were measured according to method Lichtenthaler and Buschmann (2001). Net Photosynthetic Rate (Pn) was calculated by Photosynthetic Analyzer type LI Cor LI 6400. The data were then analyzed using variance (ANOVA) $\alpha=5 \%$ significantly and regression to determine the relationship between the treatment and parameters. When the F test showed a significant effect, it will be continued with DMRT (Duncan's Multiple Range Test) $\alpha=5 \%$.

\section{RESULTS AND DISCUSSION}

Based on the preliminary experiment, the value of soil water content in the field capacity (FC) was equivalent to soil water content (SWC) by $46.9 \%$ and the wilting point (PWP) was equivalent to $25 \%$. In line with the results of measurements in the field, a permanent wilting point was obtained at $11.055 \mathrm{~kg}$, the target weight of FTSW $0,0.35$ and 0.15 were determined for each polybag. Based on the gravimetric method, the measurement of soil moisture content of FTSW 0.35 was equivalent to SWC by $32.66 \%$. Moreover, FTSW 0.15 was equivalent to SWC $28.28 \%$. Polybag weighing was done every day at $6.00 \mathrm{am}$, with an average daily temperature of $29^{\circ} \mathrm{C}-42{ }^{\circ} \mathrm{C}$.

Assessment of decreasing in leaf water potential could be an indicator of the impact of drought intensity with a reduction value of 0.1 $\mathrm{MPa}$ if the plants had a mild stress, $1.2-1.5 \mathrm{MPa}$ if the plants had a moderate stress and $>1.5 \mathrm{MPa}$ if the plants had a severe drought (Ai and Banyo, 2011). Regression analysis showed a linear relationship between moisture content and leaf 
water potential, which decreased moisture content followed by a decrease in leaf water potential. The average leaf water potential in the field capacity condition was $-0.49 \mathrm{MPa}$ down to $-1.55 \mathrm{MPa}$ at moderate drought and decreased again to -2.88 MPa in severe drought. The decrease of leaf water potential in this research indicated that the status of water in the leaf when soil water content by $32.7 \%$ had moderate stress and it had severe stress when the soil water content was $28.3 \%$. The potential decline in oil palm leaves was caused by the decline of potential groundwater (Jazayeri et al., 2015; Silva et al., 2016).

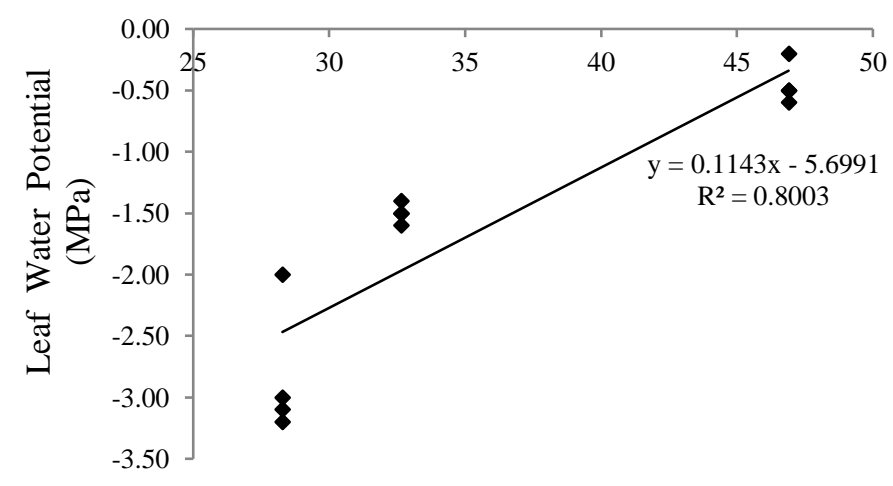

SWC (\%)

Figure 1. Regression between moisture content and leaf water potential after drought stress

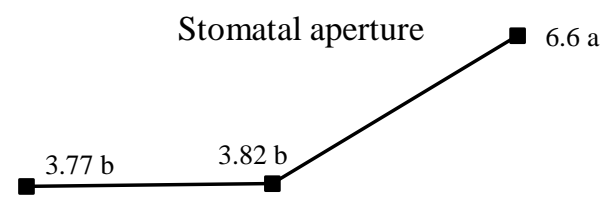

\begin{tabular}{|ccc}
\hline 28.3 & 32.7 & 46.9 \\
& SWC (\%) &
\end{tabular}

Figure 2. The stomatal aperture $(\mu \mathrm{m})$ in some soil water content under drought stress

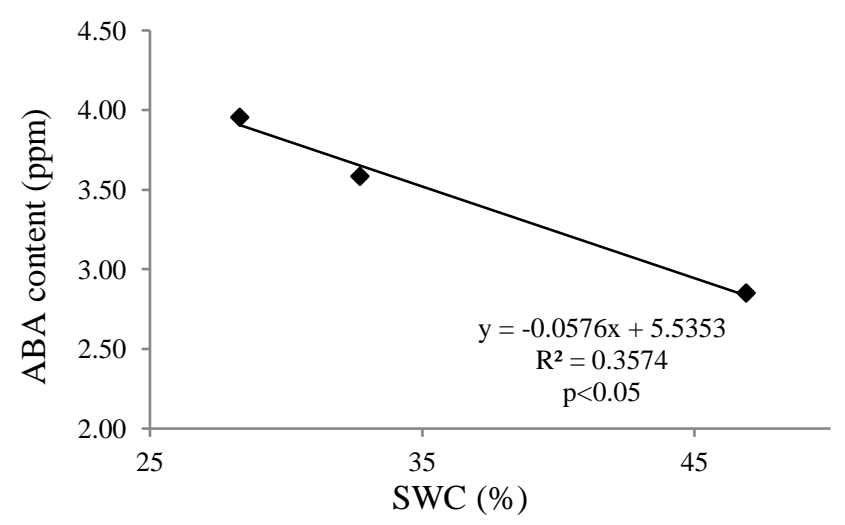

Figure 3. Regression between ABA content and soil water content

Drought stress had been shown to reduce stomatal aperture compared to controls. There were no significant differences between the effects of moderate stress and severe stress in reducing the stomatal aperture. The data showed that the drought intensity level did not limited by the decline in stomatal aperture. The decline in stomatal aperture is the first line of defense 
against dehydration (Hopper et al., 2014). The regulation of stomatal aperture was based on the level of the water deficit and may close partially, allowing carbon fixation during drought conditions with improved water use efficiency (Benesova et al., 2012). The decrement of soil moisture is the first signal received by the root that responded by the plant through stomata closure to reduce transpiration. This is the performance of $\mathrm{ABA}$ whose concentration increases from the root to the xylem sap then to the leaf organ. ABA content in the plant under drought is generally higher than in field capacity (Fathi and Tari, 2016). In this experiment, ABA content increased linearly with reduced soil water content. The increase in $\mathrm{ABA}$ concentration is a plant response to the drought signal which mediates stomatal closure to reduce transpiration. The increase in ABA concentration under drought is in line with the statement (Zhang and Jr, 2001; Fathi and Tari, 2016; Zhu, 2017) that ABA is an important stress marker hormone that accumulates and causes the stomatal closure when the plant experiences osmotic stress such as drought and high salinity.

Table 1. The effect of calcium on ABA content at calcium application levels (ppm)

\begin{tabular}{cl}
\hline Calcium $(\mathrm{g})$ & Mean \\
\hline 0.00 & $3.27 \mathrm{ab}$ \\
0.04 & $3.71 \mathrm{a}$ \\
0.08 & $2.51 \mathrm{bc}$ \\
0.12 & $2.18 \mathrm{c}$ \\
\hline
\end{tabular}

CV $25.10 \%$

Note: Different letters in each column show a significant effect at $\mathrm{p} \leq 0.05$ by Duncan's New Multiple Range Test (DMRT)

Application at the lowest dose of calcium produced the highest ABA. On the other way, the ABA measurements showed that the application of calcium at a dose $0.12 \mathrm{~g}$ significantly lower than control but no different with $0.08 \mathrm{~g}$ calcium. It was commonly known that plants responded to the decrease in leaf water potential through stomata closure regulated by ABA. Allegedly, the high calcium content in seeds with the application of 0.08 and $0.12 \mathrm{~g}$ could increase plants sensitivity to the increase in ABA concentration, particularly while experiencing moderate drought. A review of ABA signaling in stress response and seed development conducted by Nakashima and Shinozaki (2013) mention that $\mathrm{Ca}^{2+}$ signaling might have important roles for ABA signaling. Furthermore, Asano et al. (2012) stated that increasing the calcium sensor in rice seedlings causes an increase in plant sensitivity to ABA. $\mathrm{ABA}$ could induce the expression genes that were controlled by stressors, but this gene could also be expressed by the presence of $\mathrm{Ca}^{2+}$ and $\mathrm{Ca}^{2+}$-carrier even though there were no stress signals that induces ABA. The statement showed that the expression of stress marker genes was mediated by the presence of $\mathrm{Ca}^{2+}$ (Reddy, 2001). The result explained that the plants with the highest calcium were more responsive to stress signals without causing more $\mathrm{ABA}$ accumulation. As a result, the stomata not fully close and could maintain its conductivity and $\mathrm{CO}_{2}$ diffusion as well.

The measurement of chlorophyll content can be used to determine the efficiency and function of photosynthesis in plants that experience drought stress (Cha-um et al., 2010; Cha-um et al., 2013). The results revealed the influence of the interaction between calcium application and drought stress on chlorophyll $a$ content. Without calcium the effects of drought on chlorophyll $a$ content were not significantly different among SWC levels, yet tended to be higher when experiencing moderate drought. Whereas in field capacity, the application of calcium could increase the chlorophyll $a$ content as doses increase. The chlorophyll $a$ content with $0.12 \mathrm{~g}$ calcium was significantly higher than control. In moderate drought, the application of 0.08 and 0.12 $\mathrm{g}$ of calcium actually resulted in lower chlorophyll $a$ than the control and a dose of $0.04 \mathrm{~g}$ could provide the highest one. While seedlings exposed to severe drought, there were no significant differences between all calcium doses compared to control, but a dose of $0.04 \mathrm{~g}$ tended to produce the lowest chlorophyll $a$ content. In seedlings with $0.04 \mathrm{~g}$ of calcium, the chlorophyll $a$ content was higher in moderate drought and not different from field capacity. The data showed that calcium was proven to be able to prevent chlorophyll $a$ degradation even while experiencing mild stress when it was given in small amount $(0.04 \mathrm{~g})$. In contrast, $0.04 \mathrm{~g}$ sharply decreased chlorophyll $a$ even compared to the field capacity when the seeds experience severe drought. 
Table 2. The effects of interaction between drought and calcium levels on chlorophyll $a$, chlorophyll $b$ and total chlorophyll content (mg. $\left.\mathrm{L}^{-1}\right)$

\begin{tabular}{|c|c|c|c|c|}
\hline \multirow{2}{*}{ Calcium (g) } & \multicolumn{3}{|c|}{ SWC (\%) } & \multirow[t]{2}{*}{ Mean } \\
\hline & 46.9 & 32.7 & 28.3 & \\
\hline \multicolumn{5}{|l|}{ Chlorophyll $a$} \\
\hline 0.00 & $3,820.71 \mathrm{bcd}$ & $4,516.53 \mathrm{abc}$ & $3,712.29 \mathrm{bcd}$ & $4,016.51$ \\
\hline 0.04 & $4,270.91 \mathrm{abc}$ & $4,767.03 \mathrm{a}$ & $3,234.49 \mathrm{~d}$ & $4,090.81$ \\
\hline 0.08 & $4,572.21 \mathrm{ab}$ & $3,647.49 \mathrm{~cd}$ & $4,238.44 a b c$ & $4,152.71$ \\
\hline 0.12 & $4,706.97 \mathrm{a}$ & $3,362.11 \mathrm{~d}$ & $3,727.03 \mathrm{bcd}$ & $3,932.04$ \\
\hline Mean & $4,342.70$ & $4,073.29$ & $3,728.06$ & $(+)$ \\
\hline CV FTSW & & $7.20 \%$ & & \\
\hline CV Calcium & & $11.93 \%$ & & \\
\hline \multicolumn{5}{|l|}{ Chlorophyll $b$} \\
\hline 0.00 & $3,952.39$ bcde & $5,200.37 \mathrm{abc}$ & $3,703.15$ cde & $4,285.30$ \\
\hline 0.04 & $4,808.89 \mathrm{abcd}$ & $5,619.27 \mathrm{a}$ & $2,633.34 \mathrm{e}$ & $4,353.83$ \\
\hline 0.08 & $5,209.07 \mathrm{abc}$ & $3,496.25 \mathrm{de}$ & $4,740.53 \mathrm{abcd}$ & $4,481.95$ \\
\hline 0.12 & $5,509.95 \mathrm{ab}$ & $2,891.57 \mathrm{e}$ & $3,646.59$ cde & $4,016.04$ \\
\hline Mean & $4,870.07$ & $4,301.87$ & $3,680.90$ & $(+)$ \\
\hline CV FTSW & & $16.05 \%$ & & \\
\hline CV Calcium & & $19.91 \%$ & & \\
\hline \multicolumn{5}{|c|}{ Total chlorophyll } \\
\hline 0.00 & $7,770.65 \mathrm{bcd}$ & $9,713.77 \mathrm{ab}$ & $7,413.12 \mathrm{bcd}$ & $8,299.18$ \\
\hline 0.04 & $9,076.89 \mathrm{abc}$ & $10,382.93 \mathrm{a}$ & $5,866.09 \mathrm{~d}$ & $8,441.97$ \\
\hline 0.08 & $9,778.13 \mathrm{ab}$ & $7,141.53 \mathrm{~cd}$ & $8,976.09 \mathrm{abc}$ & $8,631.92$ \\
\hline 0.12 & $10,213.61 \mathrm{a}$ & $6,251.80 \mathrm{~d}$ & $7,371.33 \mathrm{bcd}$ & $7,945.58$ \\
\hline Mean & $9,209.82$ & $8,372.51$ & $7,406.66$ & $(+)$ \\
\hline CV FTSW & & $11.75 \%$ & & \\
\hline CV Calcium & & $15.97 \%$ & & \\
\hline
\end{tabular}

Note: Different letters in each column and row show a significant effect at $\mathrm{p} \leq 0.05$ by Duncan's New Multiple Range Test (DMRT). (+) indicates the treatment interaction

The similar results also occurred in chlorophyll $b$ and total chlorophyll content, where in the moderate drought conditions, calcium addition tended to reduce the chlorophyll $b$ and total chlorophyll content. However, in a severe drought there were no differences between the application of calcium and controls. The result showed that although drought has been shown to reduce the chlorophyll $a$, chlorophyll $b$ and total chlorophyll content, the effects of calcium application variably depends on the drought level.

Carotenoids are present in the chloroplasts and are bound in photosystem I and photosystem II complexes, so they have the main task in the first protection from oxidative damage (Chakraborty and Pradhan, 2012) and one of the important non- enzymatic antioxidants (Jaleel et al., 2009; Silva et al., 2016). Based on the analysis of variance, there was an interaction effect of calcium application treatment with drought stress on carotenoid content. Generally, the decrease in SWC had no effects on the carotenoid content of seeds without calcium, although it tended to be higher when experiencing drought. Carotenoid as the non-enzymatic antioxidants might represent a strategy of oil palm plants to cope with drought induced oxidative stress (Silva et al., 2016). On the other hand, in field capacity, there was no significant difference between the calcium dosage application for carotenoid content, although it tended to be higher with applied of calcium. In moderate drought application of $0.04 \mathrm{~g}$ calcium 
produced a significantly lower carotenoid content than the control, although it was not significantly different with other doses. Meanwhile, in the case of severe drought stress, the application of $0.04 \mathrm{~g}$ of calcium gave significantly higher carotenoid content than $0.08 \mathrm{~g}$ calcium but no significant compared with control. However, the plant response showed that the application of calcium did not increase the carotenoids during drought.

Table 3. The effect of interaction between drought and calcium levels on carotenoid content $\left(\mathrm{mg}^{-1} \mathrm{~L}^{-1}\right)$

\begin{tabular}{ccccc}
\hline \multirow{2}{*}{ Calcium (g) } & \multicolumn{5}{c}{ SWC $(\%)$} & Mean \\
\cline { 2 - 5 } & 46.9 & 32.7 & 28.3 & 513.03 \\
0.00 & $465.02 \mathrm{bc}$ & $535.86 \mathrm{ab}$ & $538.21 \mathrm{ab}$ & 528.04 \\
0.04 & $550.64 \mathrm{ab}$ & $397.93 \mathrm{c}$ & $635.54 \mathrm{a}$ & 487.75 \\
0.08 & $545.15 \mathrm{ab}$ & $483.14 \mathrm{bc}$ & $434.97 \mathrm{bc}$ & 526.18 \\
0.12 & $556.49 \mathrm{ab}$ & $456.05 \mathrm{bc}$ & $565.99 \mathrm{ab}$ & $(+)$ \\
\hline Mean & 529.33 & 468.25 & 543.68 & \\
\hline CV FTSW & \multicolumn{5}{c}{$13.38 \%$} \\
\hline CV Calcium & \multicolumn{5}{c}{$14.17 \%$} \\
Note: Different letters in each column and row show a significant effect at $\mathrm{p} \leq 0.05$ by Duncan's New Multiple \\
Range Test (DMRT). (+) indicates the treatment interaction
\end{tabular}

Table 4. The effect of drought and calcium levels on NRA ( $\mu \mathrm{mol} \mathrm{NO}{ }_{2}^{-} \mathrm{g}^{-1}$ hour $\left.^{-1}\right)$

\begin{tabular}{cc}
\hline Treatment & Mean \\
\hline SWC $(\%)$ & \\
46.9 & $1,356.73 \mathrm{~b}$ \\
32.7 & $2,531.54 \mathrm{a}$ \\
28.3 & $2,199.24 \mathrm{a}$ \\
\hline CV SWC & $33.99 \%$ \\
\hline
\end{tabular}

Calcium $(\mathrm{g})$

$\begin{array}{ll}0.00 & 1,558.59 \mathrm{~b} \\ 0.04 & 2,936.23 \mathrm{a} \\ 0.08 & 1,863.26 \mathrm{~b} \\ 0.12 & 1,758.61 \mathrm{~b}\end{array}$

CV Calcium

$39.16 \%$

Note: Different letters in each column show a significant effect at $\mathrm{p} \leq 0.05$ by Duncan's New Multiple Range Test (DMRT)

The major enzyme's activity such as nitrate reductase involved in the nutrient metabolism can also be significantly reduced under high temperature stress (Fahad et al., 2017). The condition is related to the decline in stomatal aperture and the concentration of $\mathrm{CO}_{2}$ in the intercellular space which is known to reduce the activity of various enzymes including nitrate reductase (Chaves et al., 2008). The results showed that there was no interaction between the application of calcium and drought stress on the NRA. However, there was a single effect of drought stress and calcium application on the
NRA. NRA in moderate and severe drought stress was significantly higher than the field capacity. The application dose of $0.04 \mathrm{~g}$ calcium could also significantly increase NRA compared to controls and other doses. This confirmed that during drought, the plant carried out a mechanism for increasing the activity of nitrate reductase as a response to abiotic stress adaptation, as shown by (Azcon and Tobar, 1998; Sepehr et al., 2012) experiment. The NRA characteristics were related to the increase in proline in this experiment. (Sharma and Dietz, 2006) reported that the increase in proline would reduce protein aggregate and denaturation due to temperature changes. In an in vitro experiment, the proline protected the activity of nitrate reductase under osmotic, metal and $\mathrm{H}_{2} \mathrm{O}_{2}$ stress.

The increase of proline content is the most sensitive plant response to reduced leaf water potential and increased osmotic pressure (Carvalho, 2008; Lokhande and Suprasanna, 2012; Liang et al., 2013). Based on the result, there were no significant differences in the effect of calcium on proline content in field capacity. Conversely, in the moderate drought there were no significantly different effects between 0.04 , 0.08 and $0.12 \mathrm{~g}$ calcium on proline content, but significantly higher than control. At severe drought, the application 0.04 and $0.08 \mathrm{~g}$ calcium was not significantly different from the control, but was significantly higher than $0.12 \mathrm{~g}$ calcium which became the lowest proline content 
compared to all treatments. Without the presence of calcium, the proline content decreases until moderate drought then sharply increases with reduced SWC. This pattern shows that plants are less sensitive to drought signals even though they eventually increase after SWC levels gradually decline.

Table 5. The effect of interaction between drought and calcium levels on proline content $\left(\mu \mathrm{mol} \mathrm{g} \mathrm{g}^{-1}\right)$

\begin{tabular}{lcccc}
\hline \multirow{2}{*}{ Calcium $(\mathrm{g})$} & 46.9 & 32.7 & 28.3 & Mean \\
\cline { 2 - 5 } & $50.30 \mathrm{~b}$ & $25.60 \mathrm{c}$ & $112.73 \mathrm{a}$ & 62.88 \\
0.00 & $43.32 \mathrm{bc}$ & $115.31 \mathrm{a}$ & $111.34 \mathrm{a}$ & 89.99 \\
0.04 & $36.76 \mathrm{bc}$ & $118.09 \mathrm{a}$ & $119.38 \mathrm{a}$ & 91.41 \\
0.08 & $37.04 \mathrm{bc}$ & $108.44 \mathrm{a}$ & $42.25 \mathrm{bc}$ & 62.58 \\
0.12 & 41.85 & 91.86 & 96.43 & $(+)$ \\
\hline \multicolumn{5}{c}{$30.88 \%$} \\
\hline Mean & \multicolumn{5}{c}{$11.20 \%$} \\
\hline CV FTSW Calcium & \multicolumn{5}{c}{} \\
\hline Note: Different letters in each column and row show a significant effect at $\mathrm{p} \leq 0.05$ by Duncan's New Multiple \\
Range Test (DMRT). (+) indicates the treatment interaction
\end{tabular}

According to Knight et al. (1998) that signal delivery requires sufficient calcium to induce the expression of genes involved in proline biosynthesis. Conversely, the addition of calcium proved to be able to induce an increase in proline since SWC levels began to decrease. This proves that calcium addition plays an important role in signal transduction which induces the expression of the $p 5 c s$ gene. The low proline content in the application of $0.12 \mathrm{~g}$ calcium in severe drought indicated the presence of other mechanisms that arise when plants get more calcium. This is related to the decline in $\mathrm{ABA}$ content at that dose because proline accumulation requires $\mathrm{ABA}$ induction when the plant is exposed to water deficit (Carvalho, 2008; Liang et al., 2013).

Table 6. The effect of interaction between drought and calcium levels on photosynthesis rate $(\mu \mathrm{mol}$ $\left.\mathrm{m}^{-1} \mathrm{~s}^{-1}\right)$

\begin{tabular}{|c|c|c|c|c|}
\hline \multirow{2}{*}{ Calcium (g) } & \multicolumn{3}{|c|}{ SWC (\%) } & \multirow{2}{*}{ Mean } \\
\hline & 46.9 & 32.7 & 28.3 & \\
\hline 0.00 & $357.33 \mathrm{a}$ & $157.33 \mathrm{e}$ & $181.67 \mathrm{de}$ & 232.11 \\
\hline 0.04 & $256.00 \mathrm{bcd}$ & 250.67 bcde & 251.67 bcde & 252.78 \\
\hline 0.08 & 244.00 bcde & $217.67 \mathrm{cde}$ & 209.33 cde & 223.67 \\
\hline 0.12 & $160.67 \mathrm{e}$ & $320.67 \mathrm{ab}$ & $277.67 \mathrm{abc}$ & 253.00 \\
\hline Mean & 254.50 & 236.58 & 230.08 & $(+)$ \\
\hline CV FTSW & \multicolumn{3}{|c|}{$5.41 \%$} & \\
\hline CV Calcium & \multicolumn{3}{|c|}{$22.45 \%$} & \\
\hline
\end{tabular}

Note: Different letters in each column and row show a significant effect at $\mathrm{p} \leq 0.05$ by Duncan's New Multiple Range Test (DMRT). (+) indicates the treatment interaction

Table 6 informs that there was an interaction between the application of calcium and drought stress on the photosynthetic rate. The photosynthetic rate of seeds without calcium application is decrease when SWC is decrease from moderate to severe. This is related to the reduction in $\mathrm{CO}_{2}$ fixation when the stomatal aperture decreases in cells that experience osmotic stress. While the increase of photosynthetic rate in seeds with a dose of $0.12 \mathrm{~g}$ calcium was present due to moderate and severe drought stress associated with a decline in ABA content. Calcium ions are reported to be involved in the opening of stomata when abscisic acid is not present (Brandt et al., 2015). The high level of $\mathrm{Ca}^{2+}$ in the guard cells was a signal to reduce 
$\mathrm{ABA}$. It made the stomata partially close and allowed the continuity of $\mathrm{CO}_{2}$ diffution. It is also believed that the increase of photosynthetic rate involves the needs for dissolved sugar as osmolyticum and an ingredient in ATP metabolism in leaves. According to Pego et al. (2000) the decline in sugar content activates the expression of assimilates enrichment genes and increases photosynthetic capacity, whereas when the sugar excess and it will suppress gene expression for photosynthesis and photosynthetic rate. In field capacity, the application of calcium tended to reduce the photosynthetic rate, conversely happened in drought stress. This experiment showed that plants have a positive response to the application of calcium through an increase in photosynthesis rate in drought. In tobacco plants exposed to heat stress, the application of exogenous calcium chloride $\left(\mathrm{CaCl}_{2}\right) \quad(20 \mathrm{mM})$ improved the process of photosynthesis concerning improving the stomatal conductance and the thermostability of oxygen-evolving complex, which might be due to less accumulation of reactive oxygen species (Tan et al., 2011).

Based on the description of each variable show that the application of calcium affects various biochemical processes that lead to the scheme of drought resistance in oil palm seedlings. This was characterized by a decline in $\mathrm{ABA}$ leaf content to prevent the stomata fully close so that $\mathrm{CO}_{2}$ diffusion might be maintained. The availability of $\mathrm{CO}_{2}$ in intracellular space is a limitation for the process of photosynthesis. The condition was supported by an increase in proline as an osmolytic, as well as an antioxidant that protects the enzyme from degradation, so the nitrate reductase activity was maintained. Although, the degradation of chlorophyll and carotenoids could not be prevented, it could be stopped at certain calcium levels. The photosynthesis rates continue to increase through an adequate supply of $\mathrm{CO}_{2}$, besides driven by the plants which need to produce assimilates and various adjustments to cope with the drought stress.

\section{CONCLUSIONS}

This study revealed that calcium as an essential element can be used to reduce the effects of drought on plants by increasing the rate of photosynthesis to prevent the stomata from closing completely so that the diffusion of $\mathrm{CO}_{2}$ continued and increased the NRA and proline accumulation to maintain cell turgor and prevented the accumulation of free radicals. The effect of calcium on chlorophyll and carotenoid under drought stress could not be explained in this study, so it is recommended for further investigation.

\section{ACKNOWLEDGEMENT}

The researchers deliver their gratitude to Department of Agronomy, Faculty of Agriculture, Gadjah Mada University and The Indonesia Endowment Fund for Education (LPDP) for the partial fund to this research.

\section{REFERENCES}

Ai, N. S., \& Banyo, Y. (2011). Konsentrasi Klorofil Daun sebagai Indikator Kekurangan Air pada Tanaman. J. Ilmiah Sain, 11(2), 166173. https://doi.org/10.1234/JIS.V11I2.202

Asano, T., Hayashi, N., Kobayashi, M., Aoki, N., Miyao, A., Mitsuhara, I., Ichikawa, H., Komatsu, S., Hirochika, J., Kikuchi, S., \& Ohsugi, R. (2012). A Rice Calcium-Dependent Protein Kinase Oscpk12 Oppositely Modulates Salt-Stress Tolerance and Blast Disease Resistance. Plant Journal, 69(1), 26-36. https://doi.org/10.1111/j.1365-313X.2011. 04766.x

Ashraf, M., \& Harris, P. J. C. (2013). Photosyn thesis under Stressful Environments: An Overview. Photosynthetica, 51(2), 163-190. https://doi.org/10.1007/s11099-013-0021-6

Bates, L. S., Waldren, R. P., \& Teare, I. D. (1973). Short Communication : Rapid Determination of Free Proline For Water-Stress Studies. Plant and Soil, 39, 205-207. online Retrieved from https://link.springer.com/article/10.1007/BF0 0018060

Benesova, M., Hola, D., Fische, L., Jedelsky, P. L., Hnilicka, F., Wilhelmova, N., Rothova, O., Kocova, M., Prochazkova, D., Honnerova, J., Fridrichova, L., \& Hnilickova, H. (2012). The Physiology and Proteomics of Drought Tolerance in Maize : Early Stomatal Closure as a Cause of Lower Tolerance to Short-Term Dehydration. Plosone, 7(6), 1-16. https://doi. org/10.1371/journal.pone.0038017

Bivi, M. S. H. R., Paiko, A. S., Khairulmazmi, A., 
Akhtar, M. S., \& Idris, A. S. (2016). Control of Basal Stem Rot Disease in Oil Palm by Supplementation of Calcium, Copper, and Salicylic Acid. Plant Pathology Journal, 32(5), 396-406. https://doi.org/10.5423/PPJ. OA.03.2016.0052

Brandt, B., Munemasa, S., Wang, C., Nguyen, D., Yong, T., Yang, P. G., Poretsky, E., Belknap, T. F., Waadt, R., Aleman, F., \& Schroeder, J. I. (2015). Calcium Specificity Signaling Mechanisms in Abscisic Acid Signal Transduction in Arabidopsis Guard Cells. $e$ Life, 1-25. https://doi.org/10.7554/eLife. 03599.018

Carr, M. K. V. (2011). A Review : The Water Relations and Irrigation Requirements of Oil Palm (Elaeis guineensis). Experimental Agriculture, 47(4), 629-652. https://doi.org/ $10.1017 /$ S0014479711000494

Carvalho, M. H. C. D. (2008). Drought Stress and Reactive Oxygen Species. Plant Signaling \& Behavior, 3(3), 156-165. Retrieved from https://www.ncbi.nlm.nih.gov/pmc/articles/P MC2634109/pdf/psb0303_0156.pdf

Cha-um, S., Yamada, N. Takabe, T., \& Kirdmanee, C. (2013). Physiological Features and Growth Characters of Oil Palm (Elaeis guineensis jacq.) in Response to Reduced Water-Deficit and Rewatering. Australian Journal of Crop Science, 7(3), 432-439. Retrieved from https://pdfs.semanticscholar. org/6856/5454279cda5e5609f4000396966d55 69de30.pdf

Cha-um, S., Takabe, T., \& Kirdmanee, C. (2010). Osmotic Potential, Photosynthetic Abilities and Growth Characters of Oil Palm (Elaeis guineensis Jacq.) Seedlings in Responses to Polyethylene Glycol-Induced Water Deficit. African Journal of biotechnology, 9(39), 6509-6516. https://doi.org/10.5897/AJB10. 809

Chakraborty, U., \& Pradhan, B. (2012). Drought Stress-Induced Oxidative Stress and Antioxidative Responses in Four Wheat (Triticum aestivum L.) Varieties. Archives of Agronomy and Soil Science, 58(6), 617-630. http://dx.doi.org/10.1080/03650340.2010.533 660

Chaves, M. M., Flexas, J., \& Pinheiro, C. (2009).
Photosynthesis Under Drought and Salt Stress : Regulation Mechanisms From Whole Plant to Cell. Annals of Botany, 103, 551-561. https://doi.org/10.1093/aob/men125

Darlan, N. H., Pradiko, I., Winarna, \& Siregar, H. H. (2016). Dampak El Nino 2015 terhadap Performa Tanaman Kelapa Sawit di Bagian Selatan Sumatera (Effect of El Nino 2015 on Oil Palm Performance in Southeastern Part of Sumatera). Jurnal Tanah dan Iklim (Indonesian Soil and Climate Journal), 40(2), 113-120. Retrieved from http://ejurnal. litbang.pertanian.go.id/index.php/jti/article/vi ew/3146

Dewi, A. Y., Putra, E. T. S., \& Trisnowati, S. (2014). Induksi Ketahanan Kekeringan Delapan Hibrida Kelapa Sawit (Elaeis guineensis) dengan Silika. Vegetalika, 3(3), 113. Retrieved from https://jurnal.ugm.ac.id/ jbp/article/viewFile/5154/4230

Fahad, S., Bajwa, A. A., Nazir, U., Anjum, S. A., Farooq, A., Zohaib, A., Sadia, S., Nasim, W., Adkins, S., Saud, S., Ihsan, M. Z., Alharby, H., Wu, C., Wang, D., \& Huang, J. (2017). Crop Production Under Drought and Heat Stress: Plant Responses and Management Options. Frontiers in Plant Science, 8, 1-16. https://doi.org/10.3389/fpls.2017.01147

Fathi, A., \& Tari, D. B. (2016). Effect of Drought Stress and its Mechanism in Plants. International Journal of Life Sciences, 10(1), 1-6. https://doi.org/10.3126/ijls.v10i1.14509

Hartiko, H. (1987). Laporan Penelitian: Optimasi Metode Pengukuran Kegiatan Nitrat Reduktase In-Vivo Daun Berbagai Species Tanaman Produksi. Yogyakarta: Fakultas Biologi UGM. 1-34. Retrieved from https://repository.ugm.ac.id/digitasi/download .php?file=3350_hjn_201307001_hari\%20hart iko.pdf

Hilu, K. W., \& Randall, J. L. (1984). Convenient Method for Studying Grass Leaf Epidermis. Taxon, 33(3), 413-415. Retrieved from https://www.jstor.org/stable/1220980?seq=1\# page_scan_tab_contents

Hopper, D. W., Ghan, R., \& Cramer, G. R. (2014). A Rapid Dehydration Leaf Assay Reveals Stomatal Response Differences in Grapevine Genotypes. Horticulture Research, 1(2), 1-8. 
https://doi.org/10.1038/hortres.2014.2

Jaleel, C. A., Manivannan, P., Wahid, A., Farooq, M., Somasundaram, R., \& Pannerselvam, R. (2009). Drought Stress in Plants : A Review on Morphological Characteristics and Pigments Composition. Int $J$ Agric, 11, 100-105. https://doi.org/08-305/IGC-DYT/2009/11-1100-105

Jazayeri, S. M., Rivera, Y. D., Camperos-Reyes, J. E., \& Romero, H. M. (2015). Physiological Effects of Water Deficit on Two Oil Palm (Elaeis guineensis Jacq.) Genotypes. Agronomía Colombiana, 33(2), 164-173. http://dx.doi.org/10.15446/agron.colomb.v33 n2.49846

Knight, H., Brandt, S., \& Knight, M. R. (1998). A history of stress alters drought calcium signalling pathways in Arabidopsis. The Plant Journal, 16(6), 681-687. https://doi.org/ 10.1046/j.1365-313x.1998.00332.x

Li, M., Wang, G., \& Lin, J. (2003). Application of External Calcium in Improving The PEGInduced Water Stress Tolerance in Liquorice Cells. Bull. Acad. Sin, 44, 275-284. Retrieved from https://ejournal.sinica.edu.tw/bbas/ content/2003/4/bot444-03.html

Liang, W., Wang, M., \& Ai, X. (2009). The Role of Calcium in Regulating Photosynthesis and Related Physiological Indexes of Cucumber Seedlings Under Low Light Intensity and Suboptimal Temperature Stress. Scientia Horticulturae, 123(1), 34-38. https://doi.org/ 10.1016/j. scienta.2009.07.015

Liang, X., Zhang, L., Natarajan, S.K., \& Becker, D. F. (2013). Proline Mechanisms of Stress Survival. Antioxidants \& Redox Signaling, 19(9), 998-1011. https://doi.org/10.1089/ars. 2012.5074

Lichtenthaler, H. K., \& Buschmann, C. (2001). Chlorophylls and Carotenoids: Measurement and Characterization by UV-VIS. Current Protocols in Food Anlytical Chemistry, 1-8. Retrieved from https://www.researchgate.net/ file.PostFileLoader.html id $=54784 \mathrm{dced} 685 \mathrm{cc}$ $45258 \mathrm{~b} 458 \mathrm{a} \&$ assetKey $=\mathrm{AS} \% 3 \mathrm{~A} 2736422927$ $44205 \% 401442252814870$

Lokhande, V. H., \& Suprasanna, P. (2012). Prospects of Halophytes in Understanding and Managing Abiotic Stress Tolerance.
Environmental Adaptations and Stress Tolerance of Plants in the Era of Climate Change, 1-54. http://dx.doi.org/10.1007/9781-4614-0815-4

Naeem, M. Naeem, M. S., Ahmad, R., \& Ahmad, R. (2017). Foliar-Applied Calcium Induces Drought Stress Tolerance in Maize by Manipulating Osmolyte Accumulation and Antioxidative Responses. Pakistan Journal of Botany, 49(2), 427-434. Retrieved from https://inis.iaea.org/search/search.aspx?orig_q $=\mathrm{RN}: 48076432$

Nakashima, K., \& Yamaguchi, S. K. (2013). ABA Signaling in Stress-Response and Seed Development. Plant Cell Rep, 32, 959-970. https://doi.org/10.1007/s00299-013-1418-1

Parry, M. A. J., Flexas, J., \& Medrano, H. (2005). Prospects for Crop Production Under Drought: Research Priorities and Future Directions. Annals of Applied Biology, 147(3), 211-226. https://doi.org/10.1111/j.1744-7348.2005. 00032.x

Pego, J. V., Kortstee, A. J., Huijser, C., \& Smeekens, S. C. M. (2000). Photosynthesis, Sugars and the Regulation of Gene Expression. Journal of Experimental Botany, 51, 407-416. https://doi.org/10.1093/jexbot/51.suppl_1.407

Putra, E. T. S., Issukindarsyah, Taryono, \& Purwanto, B. H. (2015). Physiological Responses of Oil Palm Seedlings to the Drought Stress Using Boron and Silicon Applications. Journal of Agronomy, 1-13. https://doi.org/10.3923/ja.2015.49.61

Putra, E. T. S., Issukindarsyah, Taryono, Purwanto, B.H., \& Indradewa, D. (2016). Role of Boron and Silicon in Inducing Mechanical Resistance of Oil Palm Seedlings to Drought Stress. Journal of Applied Sciences, 16(6), 242-251. https://doi.org/10.3923/jas.2016. 242.251

Ray, J. D., \& Sinclair, T. R. (1998). The Effect of Pot Size on Growth and Transpiration af Maize and Soybean During Water Deficit Stress. Journal of Experimental Botany, 49(325), 1381-1386. https://doi.org/10.1093/jxb/49. 325.1381

Reddy, A. S. N. 2001. Review Calcium: Silver Bullet in Signaling. Plant Science, 160, 381404. https://doi.org/10.1016/S0168-9452(00) 


\section{6-1}

Rosario, A., \& Tobar, R. M. (1998). Activity of Nitrate Reductase and Glutamine Synthetase in Shoot and Root of Mycorrhizal Allium Cepa Effect of Drought Stress. Plant Science, 133, 1-8. Retrieved from http://www.bashan foundation.org/contributions/AzconR/azconcepa.pdf

Sepehr, M. F., Ghorbanli, M., \& Amini, F. (2012). The Effect of Water Stress on Nitrate Reductase Activity and Nitrogen and Phosphorus Contents in Cuminum Cyminum L. Pak. J. Bot, 44(3), 899-903. Retrieved from https://inis.iaea.org/search/search.aspx?orig_q $=\mathrm{RN}: 43070450$

Shao, H. B., Chu, L., Jaleel, C. A., \& Zhao, C. (2008). Water-Deficit Stress-Induced Anatomical Changes in Higher Plants. Comptes Rendus - Biologies, 331, 215-225. https://doi.org/10.1016/j.crvi.2008.01.002

Sharma, S. S., \& Dietz, K. (2006). The Significance of Amino Acids and Amino Acid-Derived Molecules in Plant Responses and Adaptation to Heavy Metal Stress. Journal of Experimental Botany, 57(4), 711-726. https://doi.org/10.1093/jxb/erj073

Shekari, F.,Soltaniband, V., Javanmard, A., \& Abbasi, A. (2015). The Impact of Drought Stress at Different Stages of Development on Water Relations, Stomatal Density and Quality Changes of Rapeseed (Brassica napus L.). Iran Agricultural Reasearc, 34(2), 81-90. https://doi.org/10.22099/IAR.2016.3452

Silva, P. A., Oliveira, I. V., Rodrigues, K. C. B., Cosme, V. S., Bastos, A. J. R., Detmann, K. S. C., Cunha, R. L. Festucci-Buselli, R. A. DaMatta, F. M., \& Pinheiro, H. A. (2016). Leaf Gas Exchange and Multiple Enzymatic and Non-Enzymatic Antioxidant Strategies Related to Drought Tolerance in Two Oil Palm Hybrids. Trees, 30(1), 203-214. https://doi. org/10.1007/s00468-015-1289-x

Solihatun, F., Putra, E. T. S., \& Kastono, D.
(2014). Induksi Ketahanan Kekeringan Delapan Hibrida Kelapa Sawit (Elaeis guineensis) dengan Boron. Vegetalika, 3(1), 91-100. https://doi.org/10.22146/veg.5155

Song, W. Y. Zhang, Z. B., Shao, H. B., Guo, X. L., Cao, H. X., Zhao, H. B., Fu, Z. Y., \& Hu, X. J., (2008). Relationship Between Calcium Decoding Elements and Plant Abiotic-Stress Resistance. International Journal of Biological Sciences, 4(2), 116-125. https:// doi.org/10.7150/ijbs.4.116

Suguiyama, V. F., Sanches, R. F.E., Meirelles, S. T., Centeno, D. C., da Silva, E. A., \& Braga, M. R. (2016). Physiological Responses to Water Deficit and Changes in Leaf Cell Wall Composition as Modulated by Seasonality in the Brazilian Resurrection Plant Barbacenia Purpurea. South African Journal of Botany, 105, 270-278. https://doi.org/10.1016/j.sajb. 2016.03.021

Tan, W., Meng, Q. W., Brestic, M., Olsovska, K., \& Yang, X. (2011). Photosynthesis is Improved by Exogenous Calcium in Heatstressed Tobacco Plants. Journal of Plant Physiology, 168(17), 2063-2071. https://doi. org/10.1016/j.jplph.2011.06.009

Wirawan, B. D. S., Putra, E. T. Su., \& Yudono, P. (2016). Pengaruh Pemberian Magnesium, Boron dan Silikon terhadap Aktivitas Fisiologis, Kekuatan Struktural Jaringan Buah dan Hasil Pisang (Musa acuminata) "Raja Bulu". Vegetalika, 5(4), 1-14. https://doi.org/ 10.22146/veg.25675

Zhang, S. Q., \& Jr, W. H. O. (2001). Abscisic Acid Introduced Into The Transpiration Stream Accumulates in The Guard-Cell Apoplast and Causes Stomatal Closure. Plant Cell and Environment, 24, 1045-1054. https://doi.org/10.1046/j.1365-3040.2001. 00755.x

Zhu, J. (2017). Abiotic Stress Signaling and Responses In Plants. Cell, 167(2), 313-324. https://doi.org/10.1016/j.cell.2016.08.029 